\title{
Characterization of settlement patterns of red drum Sciaenops ocellatus larvae to estuarine nursery habitat: a stable isotope approach
}

\author{
Sharon Z. Herzka ${ }^{* * * *}$, Scott A. Holt, G. Joan Holt \\ Marine Science Institute, University of Texas at Austin, 750 Channelview Drive, Port Aransas, Texas 78373, USA
}

\begin{abstract}
A novel approach was used to study the settlement of red drum Sciaenops ocellatus larvae from the coastal Gulf of Mexico to a seagrass meadow in the Aransas Estuary, Texas, during an entire recruitment season (September through November 1999). Differences in the $\delta^{13} \mathrm{C}$ and $\delta^{15} \mathrm{~N}$ of the food webs supporting red drum while in the planktonic and estuarine habitats were characterized and used to identify post-settlement individuals in the process of completing the isotopic shift between the planktonic and estuarine signatures (transitional larvae). An empirical model was used to estimate the rate of change in the isotopic composition of transitional red drum to back-calculate size at settlement ( $L_{\text {setti }}$ mm standard length: SL) and time since settlement $\left(T_{\text {setti }}\right.$ d). During the period of study, there were 4 to $5 \%$ differences in the $\delta^{13} \mathrm{C}$ and $\delta^{15} \mathrm{~N}$ of planktonic larvae and 'large' settlers that had equilibrated to estuarine food sources. Red drum captured simultaneously exhibited variability in $L_{\text {sett }}$ and $T_{\text {sett }}$ values, indicating that they had settled at a range of sizes and over several days. Examination of length-frequency distributions of $L_{\text {sett }}$ estimates indicated that the smallest settlers were about $4 \mathrm{~mm} \mathrm{SL}$, peak size at settlement was 6 to $8 \mathrm{~mm} \mathrm{SL}$, and the largest settlers were 10 to $11 \mathrm{~mm} \mathrm{SL}$. Settlement dates derived from $T_{\text {sett }}$ indicated that a brief settlement pulse occurred during the latter half of September and that new settlers appeared on a daily basis throughout October and early November. The relatively continuous settlement pattern suggests a consistent supply of potential settlers to the estuary. The approach used in this study provides a fine- scale temporal resolution for the examination of settlement patterns in marine fishes that exhibit a distinct habitat transition and consequent dietary shift during early life.
\end{abstract}

KEY WORDS: Settlement $\cdot$ Fish larvae $\cdot$ Stable isotopes $\cdot$ Sciaenops ocellatus $\cdot$ Turnover

\section{INTRODUCTION}

Many marine fish species exhibit a life cycle in which adults spawn offshore and the larvae remain in the plankton for a variable period of time prior to recruiting to estuaries and occupying a demersal nursery habitat. Although the importance of recruitment of

\footnotetext{
*Present address: Departmento de Ecología, Centro de Investigación Científica y de Educación Superior de Ensenada (CICESE), Ensenada, Baja California, México. E-mail: sherzka@cicese.mx

${ }^{* *}$ Mailing address: PO Box 434844, San Diego, California 92143-4844, USA
}

larvae and early juvenile fishes to estuaries is well recognized (Bell et al. 1988, May \& Jenkins 1992, Sogard \& Able 1994, Levin et al. 1997), evaluating the role of recruitment in the local population dynamics of estuarine dependent species has proven to be a challenging task.

A critical step in the recruitment of young individuals to estuaries is 'settlement', the transition from a pelagic to a demersal habitat (Boehlert \& Mundy 1988). The window of opportunity for planktonic larvae to gain entrance to estuaries will depend not only on the physical and behavioral processes that favor their transport to nursery habitat (Weinstein et al. 1980, Fortier \& Leggett 1983, Norcross \& Shaw 1984), but 
also on their ability to respond to the environmental cues that trigger settlement (Victor 1991). Hence, settlement is constrained by the size and/or age at which larvae become competent to settle. Identification of the sizes at which larvae are most likely to settle would be useful when quantifying the abundance of potential settlers (McCormick 1994, Danilowicz 1997).

Another critical aspect of estuarine recruitment involves the temporal scales over which settlement occurs. By examining fine-scale temporal patterns of settlement, it is possible to determine whether it occurs periodically, in pulses, or as the result of continuous input of new recruits (Doherty 1991). Such information is crucial for identifying the processes that transport larvae to estuaries and evaluating the relationship between larval supply and settlement (Miller 1988, Milicich et al. 1992, Shenker et al. 1993).

This study attempts to characterize the fine-scale temporal settlement patterns of red drum (Sciaenops ocellatus; Sciaenidae) to a site in the Aransas Estuary, Texas, USA. Red drum is an estuarine-dependent species that supports a substantial recreational fishery in the northern Gulf of Mexico. Adults are synchronous batch spawners that reproduce in shelf waters and near tidal inlets (Bass \& Avault 1975, Wilson \& Nieland 1994). Larvae remain in the plankton for 2 to $3 \mathrm{wk}$ prior to recruiting to estuaries (Comyns et al. 1989, Rooker \& Holt 1997).

The Aransas Estuary provides an extensive nursery habitat for red drum recruits, which preferentially occupy Halodule wrightii meadows (Rooker et al. 1998a). Ongoing studies suggest that planktonic red drum are transported into the estuary when coastal waters are driven into the system through the Aransas Pass tidal inlet as a result of tidal or non-tidal forcing

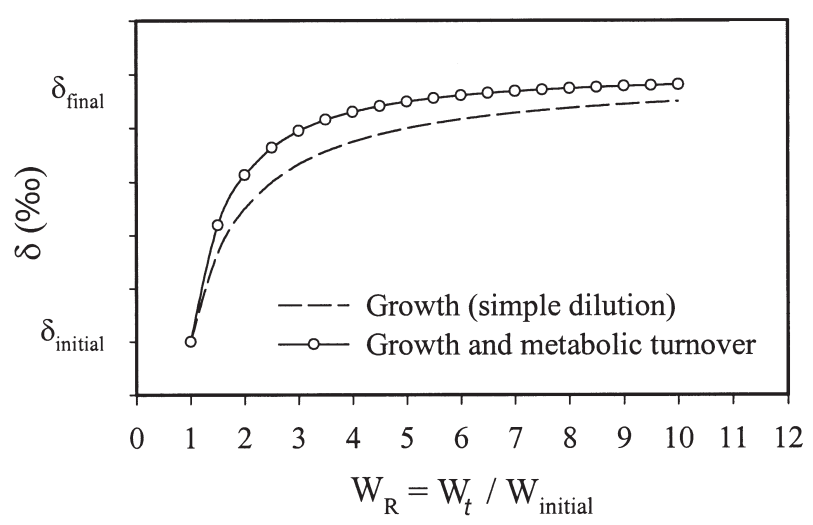

Fig. 1. Expected pattern of isotopic change exhibited by tissues of a newly settled larva. Growth is expressed in terms of relative biomass increase $\left(W_{\mathrm{R}}\right) . W_{t}$ and $W_{\text {initial }}$ are the weight at time $t$ after and at the time of the change in diet, respectively
(Brown et al. 2000). In addition, planktonic larvae are capable of migrating vertically in response to flood and ebb tides, and probably use currents for transport into the estuary (Holt et al. 1989). Red drum do not exhibit a distinct metamorphosis at the sizes corresponding to settlement (Holt 1990), nor do they possess an identifiable otolith settlement mark. Based on the size distribution of post-settlement red drum, recent settlers first appear in nursery habitat at a standard length (SL) of $4 \mathrm{~mm}$ and appear to complete settlement by 8 to $9 \mathrm{~mm}$ SL (Peters \& McMichael 1987, Rooker et al. 1998a). Nevertheless, it is difficult to distinguish between new and recent settlers captured in the same collection.

To examine settlement in red drum, we used the differences in the isotopic composition of the food sources available to this species while in planktonic and estuarine habitats (Fry 1983, France 1995, Deegan \& Garritt 1997). The isotopic composition of local food webs is reflected in the $\delta^{13} \mathrm{C}$ and $\delta^{15} \mathrm{~N}$ of animal tissues (DeNiro \& Epstein 1978, 1981). After settlement the isotopic composition of red drum will gradually shift from a planktonic signature to one reflecting benthic estuarine foods. We developed an empirical model that relies on $\delta^{13} \mathrm{C}$ and $\delta^{15} \mathrm{~N}$ measurements of pre- and postsettlement red drum and growth rate estimates to back-calculate size at settlement $\left(L_{\text {sett }}\right)$ and time since settlement $\left(T_{\text {sett }}\right)$ for individuals collected in the nursery habitat (Herzka et al. 2001). The model can be used to estimate the date of settlement for individuals in order to reconstruct daily settlement patterns from periodic collections of post-settlement red drum.

The objectives of this study were to use the settlement model to reconstruct the daily settlement pattern and examine the size distribution of newly settled individuals during a complete recruitment season. In addition, we attempted to characterize the carbon sources and food web structure leading to differences in the $\delta^{13} \mathrm{C}$ and $\delta^{15} \mathrm{~N}$ of red drum inhabiting coastal and estuarine areas.

\section{MATERIALS AND METHODS}

Model overview. Given an adequate difference in the isotopic composition of the food web supporting pre- and post-settlement red drum, the isotopic signature of a newly settled individual will shift toward that of estuarine food sources. The planktonic signature is rapidly diluted by biomass gain, although metabolic turnover accelerates the rate of isotopic change relative to that predicted based on growth alone (simple dilution conditions). The expected isotopic composition at a given time during the shift $\left(\delta_{t}\right)$ can be described using the following hyperbolic relationship (Fry \& Arnold 1982; Fig. 1): 


$$
\delta_{t}=\delta_{\text {final }}+\left(\delta_{\text {initial }}-\delta_{\text {final }}\right) \times\left(W_{\mathrm{R}}\right)^{c}, \text { where } W_{\mathrm{R}}=\frac{W_{t}}{W_{\text {initial }}}
$$

where $\delta_{\text {final }}$ represents the isotopic composition of postsettlement larvae that have reached an equilibrium with estuarine food sources, $\delta_{\text {initial }}$ is the isotopic composition of planktonic larvae, and $W_{\mathrm{R}}$ is the biomass gain (dry wt) relative to that at the time of the dietary switch $\left(W_{\text {initial }}\right)$. The empirically-derived value of the exponent of metabolic decay $(c)$ represents the contribution of metabolic turnover to isotopic change. When $C=-1$, isotopic changes are a result of biomass gain and the consequent dilution of the initial isotopic signature. When $c<-1$, metabolic turnover accelerates isotopic change (Fry \& Arnold 1982).

This relationship was used to estimate standard length at settlement $\left(L_{\text {sett, }} \mathrm{mm}\right)$ and time since settlement $\left(T_{\text {sett, }}\right.$ d) for transitional post-settlement red drum (Herzka et al. 2001). Transitional individuals are those with an isotopic composition between $\delta_{\text {initial }}$ and $\delta_{\text {final }}$. To estimate $L_{\text {sett, }}$ Eq. (1) was solved for $W_{\text {initial }}$ :

$$
W_{\text {initial }}=\left[\frac{\left(\delta_{t}-\delta_{\text {final }}\right)}{\left(\delta_{\text {initial }}-\delta_{\text {final }}\right)} \cdot W_{t}^{-c}\right]^{1 /-c}
$$

A length-weight relationship specific to red drum $(W=$ $0.0019 L^{3.3}$; [ $W$ in mg dry wt and $L$ in $\mathrm{mm} \mathrm{SL}$ ] for individuals between 2.5 and $15 \mathrm{~mm} \mathrm{SL}$; see Herzka \& Holt 2000) was used to convert $W_{\text {initial }}$ to $L_{\text {sett }}$. $T_{\text {sett }}$ can be calculated using the following relationship:

$$
T_{\text {sett }}=-\frac{1}{g b c} \ln \left(\frac{\delta_{\text {initial }}-\delta_{\text {final }}}{\delta_{t}-\delta_{\text {final }}}\right)
$$

where $g$ is the instantaneous growth rate $\left(\mathrm{d}^{-1}\right)$ and $b$ is the exponent of the length-weight relationship described above. A more thorough explanation of the model can be found in Herzka (2000) and Herzka et al. (submitted).

The exponents of metabolic decay used in this study ( $C=-1.4$ and -1.3 for $\delta^{13} \mathrm{C}$ and $\delta^{15} \mathrm{~N}$, respectively) were derived by simulating a settlement event using caged fish and examining the change in the isotopic composition of red drum tissues as a function of growth (Herzka et al. 2001). That study was conducted concurrently with the collection of red drum recruits in the Aransas Estuary (see below), and therefore approximated the natural conditions encountered by post-settlement red drum undergoing a dietary change. We assumed that the contribution of metabolic turnover to the rate of isotopic change exhibited by red drum was constant throughout the season. In previous studies, we were unable to identify a consistent trend between growth rate or temperature and the value of $c$ (Herzka \& Holt 2000, Herzka et al. 2001).

The instantaneous growth coefficient $(g)$ was also assumed to be constant. Rooker \& Holt (1997) reported growth rates for 6 cohorts of post-settlement red drum collected in the Aransas Estuary ranging from 0.041 to $0.058 \mathrm{~d}^{-1}$ and averaging $0.048 \mathrm{~d}^{-1}$. Sensitivity analysis of the settlement model indicated that growth rate variations of this magnitude result in a maximum difference of about $25 \%$ in $T_{\text {sett }}$ estimates (Herzka et al. 2001). For example, for individuals settling 2 and $6 \mathrm{~d}$ prior to the date of capture, the potential error would be $<1$ and $1.5 \mathrm{~d}$, respectively. Therefore, assuming a constant $g$ is unlikely to severely alter model results.

Red drum collections and isotopic analysis. The value of $\delta_{\text {initial }}$ was derived by characterizing the $\delta^{13} \mathrm{C}$ and $\delta^{15} \mathrm{~N}$ of pre-settlement red drum collected in the Aransas Estuary and nearshore Gulf of Mexico. Collections of pre-settlement red drum were conducted between September and early November 1999. Fixed and towed plankton nets were used to sample in Lydia Ann Channel, the Aransas Pass tidal inlet, and coastal Gulf of Mexico near the inlet (Fig. 2). A previous study suggested that planktonic red drum exhibit limited spatial variability in isotopic composition (Herzka et al. 2001). However, there were temporal differences, so sampling was conducted frequently in order to incorporate changes in the value of $\delta_{\text {initial }}$ within the model. Samples were placed on ice for transport to the laboratory, where red drum were extracted and frozen pending isotopic analysis.

Post-settlement red drum were collected at a site in Aransas Bay twice weekly between 16 September and 15 November 1999. The North Pass station is located on the estuarine side of San Jose Island, which separates the Aransas Estuary from the Gulf of Mexico

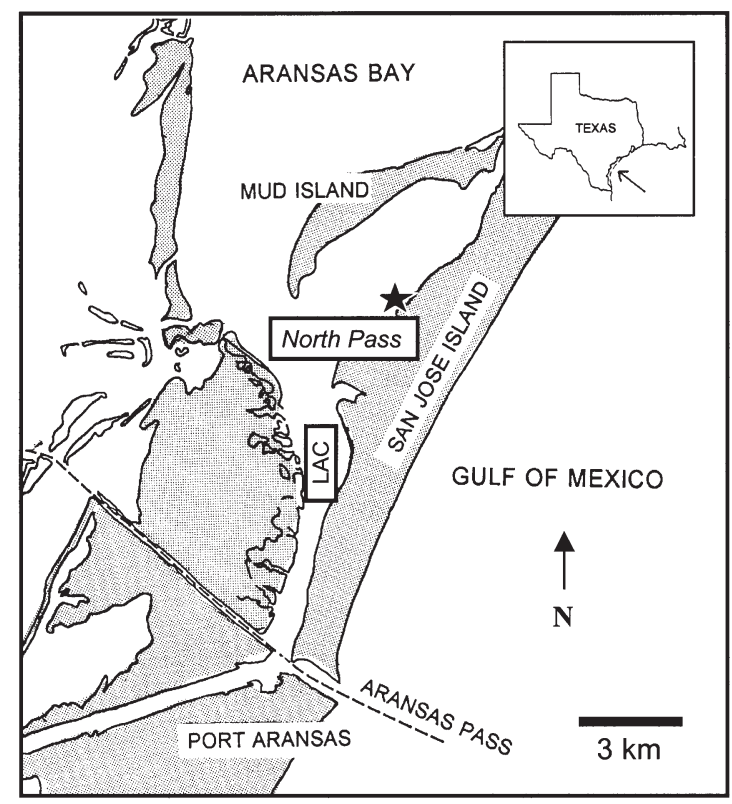

Fig. 2. Map of study area. „: North Pass study site $\left(27^{\circ} 54^{\prime} 21^{\prime \prime} \mathrm{N}, 97^{\circ} 02^{\prime} 17^{\prime \prime} \mathrm{W}\right)$. LAC: Lydia Ann Channel 
(Fig. 2). Potential recruits must be transported through Lydia Ann Channel (LAC; ca $6 \mathrm{~km}$ ) before reaching Aransas Bay. The site is located in the middle of an expanse of seagrass (primarily Halodule wrightii), ca $2.5 \mathrm{~km}$ long and $1 \mathrm{~km}$ wide, which extends parallel to San Jose Island on the east side of Aransas Bay. Substantial numbers of post-settlement red drum have been collected in this area during the course of previous studies (Rooker \& Holt 1997, Rooker et al. 1998a, 1999). On each collection date, 5 tows were taken with a hand-towed epibenthic sled covering $15 \mathrm{~m}^{2}$ with each pass (see Rooker et al. 1998a for details). Samples were placed in buckets and dead seagrass leaves and macroalgae were discarded. Red drum were removed and placed in a container of seawater kept on ice.

In the laboratory, SL was measured to the nearest $0.1 \mathrm{~mm}$ using an ocular micrometer, and fish were frozen individually for later $\delta^{13} \mathrm{C}$ and $\delta^{15} \mathrm{~N}$ analysis. The material remaining in the bucket was preserved in $10 \%$ formalin. Red drum were later sorted from preserved samples and measured. No attempt was made to correct for the effect of preservation (chilling in seawater and fixing in formalin) on SL measurement because such effects are minimal and tend to vary among individuals (Peters \& McMichael 1987). To examine the temporal abundance of post-settlement late larvae and early juveniles, SL measurements were rounded to the nearest $\mathrm{mm}$ and length-frequency distributions were generated for each collection date. Red

Table 1. Sciaenops ocellatus. $\delta^{13} \mathrm{C}$ and $\delta^{15} \mathrm{~N}$ (mean $\pm \mathrm{SD}$ ) of planktonic red drum in 1999; n: number of pooled samples analyzed for a given collection date. Consecutive sampling dates in which larvae had similar $\delta^{13} \mathrm{C}$ or $\delta^{15} \mathrm{~N}$ (within $1 \%$ ) were identified; the average isotopic composition was calculated and used as $\delta_{\text {initial }}$ in the settlement model. $\mathrm{A} \delta^{13} \mathrm{C}_{\text {initial }}$ of $-18.1 \%$ o (C-1) was applied to red drum collected on or before 12 October; a value of $-18.6 \%$ was applied to larvae collected after that date. Examination of the $\delta^{15} \mathrm{~N}$ values of post-settlement red drum indicated that small larvae with enriched nitrogen values (ca 14 to $15 \%$ ) were present in the nursery habitat only during the collections completed on 8 and 12 October. Hence, a $\delta^{15} \mathrm{~N}_{\text {initial }}$ of $13.1 \%$ (N-1), $14.4 \%$ ( $\left.\mathrm{N}-2\right)$ and $13.3 \%(\mathrm{~N}-3)$ were used for fish collected on or before 5 October, from 8 to 12 October, and for the remainder of the season, respectively

\begin{tabular}{|c|c|c|c|c|c|c|}
\hline $\begin{array}{r}\mathrm{Co} \\
\text { no. }\end{array}$ & $\begin{array}{r}\text { ection } \\
\text { date }\end{array}$ & $\mathrm{n}$ & $\begin{array}{c}\delta^{13} \mathrm{C} \\
(\% \circ)\end{array}$ & Period & $\begin{array}{c}\delta^{15} \mathrm{~N} \\
(\% \circ)\end{array}$ & Period \\
\hline 1 & $21 \mathrm{Sep}$ & 3 & $-18.1 \pm 0.2$ & C-1 & $13.1 \pm 0.4$ & N-1 \\
\hline 2 & 5 Oct & 1 & -18.3 & $C-1$ & 14.3 & $\mathrm{~N}-2$ \\
\hline 3 & 6 Oct & 4 & $-18.0 \pm 0.2$ & C-1 & $14.5 \pm 0.1$ & $\mathrm{~N}-2$ \\
\hline 4 & 7 Oct & 4 & $-17.9 \pm 0.2$ & C-1 & $13.0 \pm 0.2$ & N-3 \\
\hline 5 & 11 Oct & 4 & $-18.7 \pm 0.2$ & C-2 & $13.8 \pm 0.1$ & $\mathrm{~N}-3$ \\
\hline 6 & 13 Oct & 5 & $-18.6 \pm 0.2$ & C-2 & $13.4 \pm 0.3$ & N-3 \\
\hline 7 & 21 Oct & 2 & $-19.0 \pm 0.1$ & C-2 & $13.1 \pm 0.4$ & N-3 \\
\hline 8 & 26 Oct & 7 & $-18.4 \pm 0.2$ & C-2 & $13.0 \pm 0.3$ & N-3 \\
\hline
\end{tabular}

drum juveniles $>20 \mathrm{~mm}$ SL were excluded because of size-selectivity of the sampling gear (Rooker et al. 1999).

An estimate of the maximum size at which red drum can be expected to attain $\delta_{\text {final }}$ was derived in order to identify a cutoff point for the selection of individuals to be analyzed for $\delta^{13} \mathrm{C}$ and $\delta^{15} \mathrm{~N}$. Given that an individual should approximate $\delta_{\text {final }}$ after a $\sim 5$-fold increase in biomass (Herzka \& Holt 2000), a fish settling at the conservatively large size of $10 \mathrm{~mm}$ SL (3.8 mg dry wt; see Peters \& McMichael 1987, Rooker et al. 1998a) should reach $\delta_{\text {final }}$ by about $16 \mathrm{~mm}$ SL (18 $\mathrm{mg}$ dry wt). Therefore, all frozen individuals smaller than $16 \mathrm{~mm}$ SL were selected for isotopic analysis. This approach led to the analysis of all transitional individuals while including those that had equilibrated on estuarine food sources. Because of the large number of red drum collected on 4 November $1999(n=56)$, half were randomly selected for isotopic analysis.

$\delta^{13} \mathrm{C}$ and $\delta^{15} \mathrm{~N}$ analysis was performed on the larvae after dissecting and removing digestive tracts to avoid contamination of isotopic ratios by food items. Following dissection, red drum larvae were dried at $60^{\circ} \mathrm{C}$ for 24 to $48 \mathrm{~h}$. Because of the small size of planktonic larvae, up to 5 individuals were pooled to obtain sufficient material for isotopic analysis. Post-settlement red drum were analyzed individually. Isotopic measurements were made on a (Thermo Finnegan DeltaPlus MAT, Bremen, Germany) stable isotope ratio mass spectrometer at the University of Texas Marine Science Institute in Port Aransas, Texas, USA. $\delta^{13} \mathrm{C}$ is expressed relative to PeeDee Belemnite and $\delta^{15} \mathrm{~N}$ relative to atmospheric nitrogen.

Food web characteristics. Particulate organic matter $\left(\mathrm{POM}_{i}<40,40\right.$ to 200 and $\left.>200 \mu \mathrm{m}\right)$ was collected in the coastal Gulf of Mexico and in Aransas Bay during the middle of the settlement season (12 to 15 October 1999). In the Gulf of Mexico, POM was collected at 2 nearshore sites within $4 \mathrm{~km}$ of the tidal inlet. In Aransas Bay, POM samples were collected next to the North Pass site and close to Lydia Ann Channel. To collect POM $<40 \mu \mathrm{m}, 3$ surface water samples were filtered through a $40 \mu \mathrm{m}$ Nitex sieve to remove large particles and subsequently filtered onto $0.2 \mu \mathrm{m}$ precombusted GF/F filters. The filters were rinsed twice with distilled water prior to freezing. For larger POM, a $35 \mu \mathrm{m}$-mesh $1 \mathrm{~m}$ plankton net was actively towed. The material collected was rinsed throughly in distilled water and size-fractionated using Nitex sieves to yield POM in the 40 to $200 \mu \mathrm{m}$ and $>200 \mu \mathrm{m}$ size range.

At the North Pass site, seagrass leaves, abundant species of drift macroalgae, and the leaves of wetland plants found adjacent to the seagrass meadow were collected and placed on ice. In the laboratory, plant samples were examined under a dissecting microscope, 
attached organisms were removed, and a clean leaf section was removed and rinsed in distilled water. Samples from at least 4 individual plants were pooled, dried, and ground to a fine powder in preparation for isotopic analysis. Seagrass epiphytic material was scraped onto GF/F filters. Four surface sediment organic matter (SOM) samples were collected (top 1 to $2 \mathrm{~cm}$ ) with a $60 \mathrm{ml}$ plastic syringe from which the end had been removed. Individual SOM samples were dried and acidified by fuming under $1 \mathrm{M} \mathrm{HCl}$ for $1 \mathrm{~h}$ to remove inorganic carbonates. All samples were dried at $60^{\circ} \mathrm{C}$ for 24 to $48 \mathrm{~h}$ prior to grinding. Isotopic analyses were conducted as described in the preceding subsection.

\section{RESULTS}

\section{Isotopic composition of planktonic red drum}

Planktonic red drum were captured on 8 dates between 21 September and 26 October 1999. The mean isotopic composition of the larval samples ranged from -17.9 to $-19.0 \%$ for $\delta^{13} \mathrm{C}$ and 13.0 to $14.5 \%$ for $\delta^{15} \mathrm{~N}$ (Table 1). Because the settlement model is sensitive to the value of $\delta_{\text {initial, }}$ (Herzka et al. 2001), the consecutive sampling dates on which larvae had similar $\delta^{13} \mathrm{C}$ or $\delta^{15} \mathrm{~N}$ (defined as isotopic values within $1 \%$ o) were identified and partitioned into different periods. The average isotopic composition of the larvae was calculated for each period and the resulting values were used as $\delta_{\text {initial }}$ in the model (see Table 1 for further details).

\section{Abundance and isotopic composition of post-settlement red drum}

A total of 362 post-settlement red drum (late larvae and early juveniles up to $20 \mathrm{~mm}$ SL) were captured during 16 collections conducted at the North Pass site between 16 September and 15 November 1999 (Fig. 3). The average temperature and salinity during that period were $24.1 \pm 1.0^{\circ} \mathrm{C}$ and $29 \pm 0.8 \%$ o (mean $\pm \mathrm{SE}$; $\mathrm{n}=16)$. The average depth was $48 \pm 4 \mathrm{~cm}$.

Based on the length-frequency distribution of post-settlement red drum, Rooker et al. (1998a) suggested that red drum settle by $8 \mathrm{~mm}$ SL. Likewise, Peters \& McMichael (1987) were unable to find planktonic red drum $>8 \mathrm{~mm}$ SL in open waters of Tampa Bay, Florida, and therefore suggested that red
Dry weight (mg)
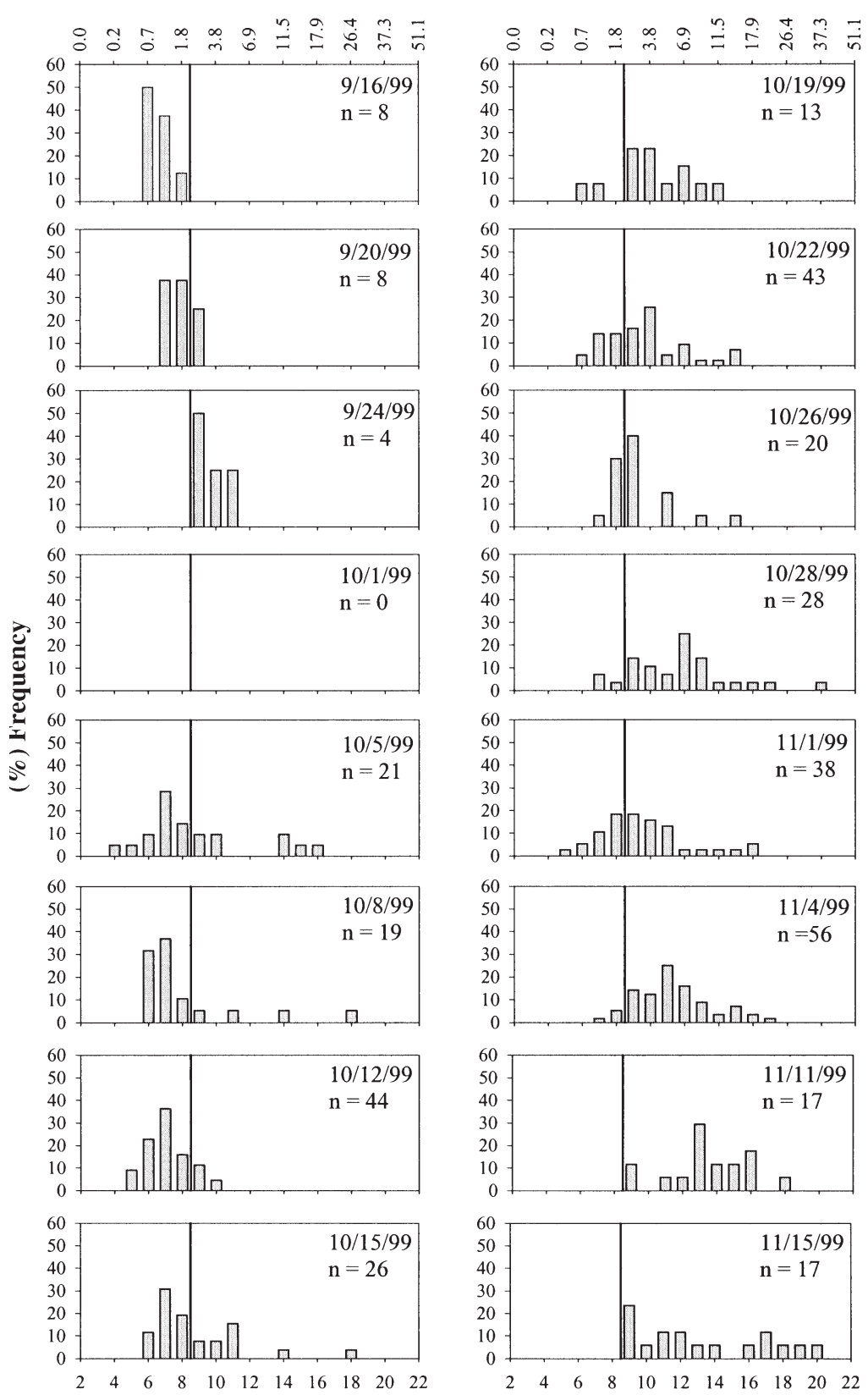

Standard length (mm)

Fig. 3. Sciaenops ocellatus. Length-frequency distributions of post-settlement larvae collected at North Pass in 1999. Each millimeter size class is centered on an integer value. Vertical black lines divide settlement-size red drum $(\leq 8 \mathrm{~mm}$ standard length, SL) from larger late larvae and early juveniles. n: number of post-settlement red drum collected. Dates presented as mo/d/yr 
drum settle at $\leq 8 \mathrm{~mm}$ SL. Using this criterion to identify recent settlers, 139 settlement-size individuals were captured in the nursery habitat site at North Pass during the study period (Fig. 3). Although a few were collected in September, most were captured between 5 October and 1 November.

Isotopic analysis was done for 224 post-settlement red drum $\leq 16 \mathrm{~mm} \mathrm{SL}$. Their $\delta^{13} \mathrm{C}$ and $\delta^{15} \mathrm{~N}$ at the time of capture were plotted as a function of their dry weight and SL to identify the settlers that had equilibrated to estuarine food sources (Fig. 4). Although the isotopic values of red drum larvae $<10 \mathrm{mg}(\sim 13 \mathrm{~mm} \mathrm{SL})$ were highly variable, a clear trend from a planktonic signature (ca-18 and 13 to $15 \%$ for carbon and nitrogen, respectively) to one reflecting estuarine food sources (ca -13 and 9\% for carbon and nitrogen, respectively) was observed. The high variability in the isotopic composition of red drum $\leq 10 \mathrm{mg}(13.4 \mathrm{~mm} \mathrm{SL})$ reflects the presence of transitional larvae. With the exception of 4 individuals (out of 37 ) that were treated

Standard length $(\mathrm{mm})$
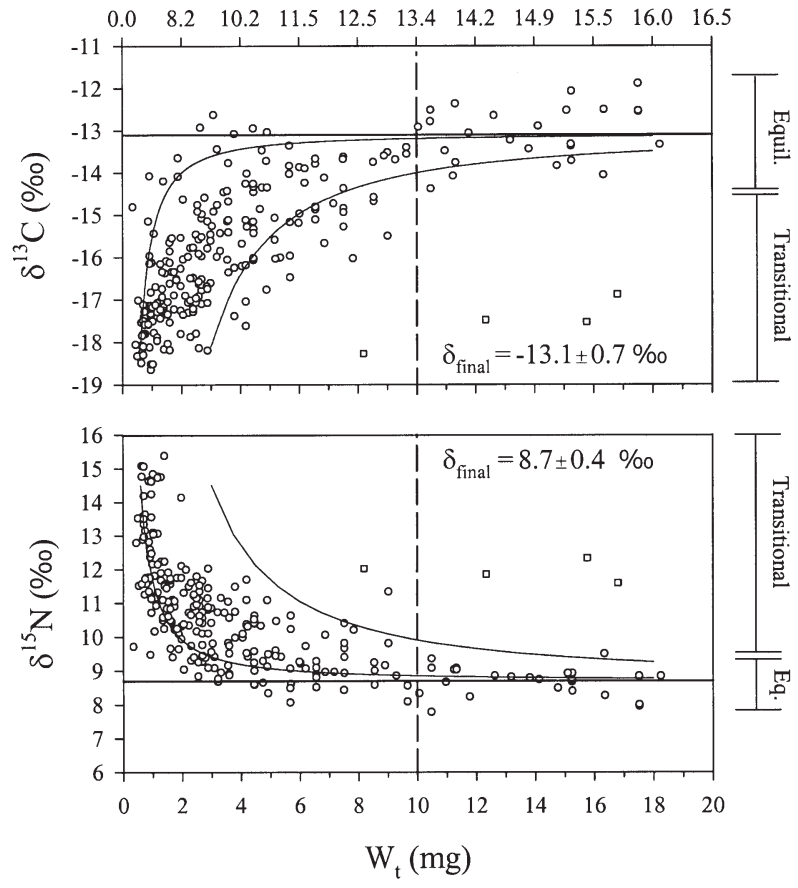

Fig. 4. Sciaenops ocellatus. $\delta^{13} \mathrm{C}$ and $\delta^{15} \mathrm{~N}$ of post-settlement larvae expressed as a function of dry weight and standard length at the time of collection. $\delta_{\text {final }}$ (horizontal continuous line) was calculated as the mean isotopic composition of individuals $>10 \mathrm{mg}$ (data to right of dashed vertical line). Four large fish (ㅁ) with depleted $\delta^{13} \mathrm{C}$ and enriched $\delta^{15} \mathrm{~N}$ values were considered outliers. For illustrative purposes, the predicted pattern of isotopic change exhibited by a $0.6 \mathrm{mg}$ larva (5.7 mm SL, left curve) and a $3.0 \mathrm{mg}$ larva $(9.3 \mathrm{~mm} \mathrm{SL}$, right curve) are included. Eq., Equil.: equlibrium as outliers because of their 'plankton-like' signature at a relatively large size (13 $\mathrm{mm}$ SL or larger), all large red drum (>10 mg dry wt) exhibited similar isotopic values. The mean $\delta^{13} \mathrm{C}$ and $\delta^{15} \mathrm{~N}$ of these individuals was calculated and used as $\delta_{\text {final }}$ in the settlement model (mean $\pm \mathrm{SD}: \delta^{13} \mathrm{C}_{\text {final }}=-13.1 \pm 0.7 \%$ and $\delta^{15} \mathrm{~N}_{\text {final }}=8.7 \pm 0.4 \%$; $\mathrm{n}=25$ ). All individuals whose isotopic composition was within $2 \mathrm{SD}$ of $\delta_{\text {final }}$ were considered equilibrated, and were therefore not utilized to derive estimates of $L_{\text {sett }}$ and $T_{\text {sett }}$.

\section{Size at settlement}

A total of $155\left(\delta^{13} \mathrm{C}\right)$ and $140\left(\delta^{15} \mathrm{~N}\right)$ red drum were identified as transitional. The settlement model was used to estimate settlement sizes for the fish captured on each date of collection (Fig. 5a,b). The high variability in the values of $L_{\text {sett }}$ on a given collection date reflects the presence of red drum at different stages of isotopic change. Regression of $L_{\text {sett }}$ on estimated settlement date (derived with $T_{\text {sett }}$ estimates: see below) was used to evaluate the presence of temporal trends in settlement sizes. For both $\delta^{13} \mathrm{C}$ - and $\delta^{15} \mathrm{~N}$-based data sets, there was a significant increase in the size of new settlers with time (Fig. 5c,d). Most of the transitional larvae collected early in the season (September) were estimated to have settled at relatively small sizes (5 to $7 \mathrm{~mm} \mathrm{SL}$ ). During the peak of the settlement season (October), red drum exhibited a large range in settlement sizes (ca 4 to $11 \mathrm{~mm} \mathrm{SL}$ ), probably reflecting the greater size range of larvae in the plankton. Based on the frequency distributions of $L_{\text {sett }}$ (Fig. 5e,f), the peak settlement sizes were 6 to $8 \mathrm{~mm}$ SL for both $\delta^{13} \mathrm{C}$ and $\delta^{15} \mathrm{~N}$-based estimates, and $97 \%$ of red drum were estimated to have settled within 5 to $10 \mathrm{~mm}$ SL. Lengthfrequency distributions of newly settled red drum derived from the $\delta^{13} \mathrm{C}$ and $\delta^{15} \mathrm{~N}$-based data sets did not differ significantly (Mann-Whitney $U$-test $=50.5 ; \mathrm{p}=$ $0.38,1 \mathrm{df})$.

\section{Examination of temporal settlement patterns}

To reconstruct the daily settlement patterns, 2 corrections were applied to the data. The first correction accounted for not performing isotopic analysis on all red drum $\leq 16 \mathrm{~mm}$ SL captured on any one sampling date. For the 15 dates on which red drum were captured, on average $75 \%$ (range 65 to $100 \%$ ) of the fish $\leq 16 \mathrm{~mm}$ SL were removed and analyzed. Although the number of fish in each collection was generally too small to perform a reliable statistical analysis to test whether the size distributions of frozen and preserved fish were the same, visual inspection of the data did 

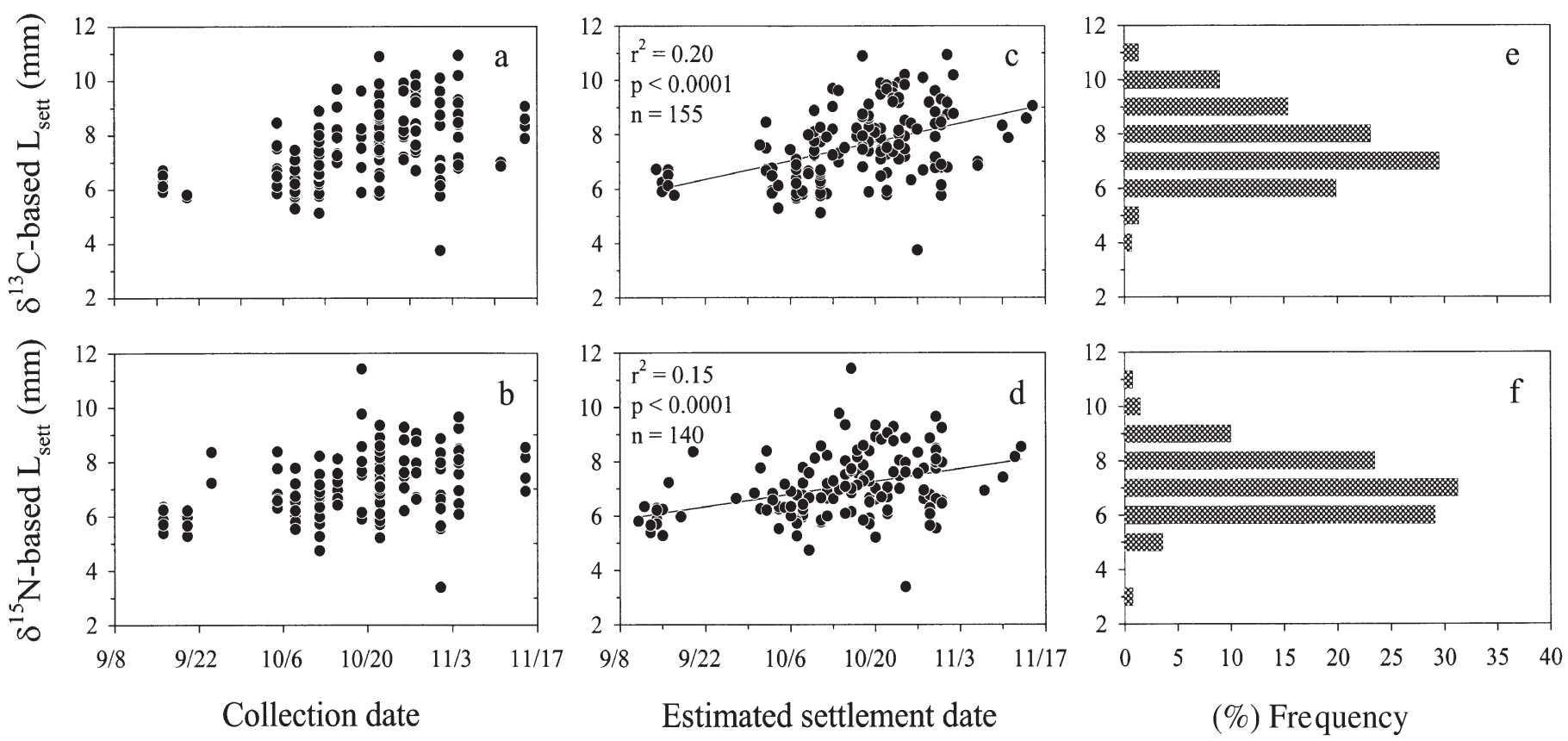

Fig. 5. Sciaenops ocellatus. (a) $\delta^{13} \mathrm{C}$ and (b) $\delta^{15} \mathrm{~N}$-based estimates of size at settlement $\left(L_{\text {sett }}\right)$ for larvae collected on each sampling date. Relationship between settlement size $\left(L_{\text {sett }}\right)$ and estimated settlement date derived using (c) $\delta^{13} \mathrm{C}$ and (d) $\delta^{15} \mathrm{~N}$ data was examined using regression analysis; continuous lines represent linear regression results; coefficients of determination $\left(\mathrm{r}^{2}\right)$, $\mathrm{p}$ values, and linear equations are provided. Frequency distributions of settlement sizes derived using (e) $\delta^{13} \mathrm{C}$ and (f) $\delta^{15} \mathrm{~N}$ data, respectively. Dates presented as mo/d

not suggest systematic undersampling of any size range. To generate a corrected estimate of the number of transitional fish in each collection, the total number of red drum $\leq 16 \mathrm{~mm}$ SL captured was multiplied by the proportion of transitional fish found among those analyzed for $\delta^{13} \mathrm{C}$ and $\delta^{15} \mathrm{~N}$. For each date, a weighting factor representing the contribution of each fish analyzed to the total number of transitional fish present on a given collection date was calculated. For example, if 7 out of 10 transitional fish were analyzed, then the data for each larva would represent 1.4 (i.e. 10/7) individuals in the reconstruction of daily settlement patterns.

The second correction accounted for differences in the cumulative mortality experienced by post-settlement red drum. In the Aransas Estuary, post-settlement mortality is considerable (Rooker et al. 1999), so earlier settlers would be underepresented in daily settlement estimates. A mortality correction was applied to each individual using the equation of Brown \& Bailey (1992):

$$
N_{\text {sett }}=\mathrm{e}^{Z d}
$$

where $N_{\text {sett }}$ is the corrected number of fish at the time of settlement, $Z$ is the instantaneous mortality coefficient $\left(\mathrm{d}^{-1}\right)$ and $d$ represents the estimated number of days elapsed since settlement $\left(T_{\text {sett }}\right)$. Rooker et al. (1999) found limited interannual variability in instanta- neous mortality coefficients $\left(Z=0.134\right.$ and $\left.0.137 \mathrm{~d}^{-1}\right)$ for post-settlement red drum in the Aransas Estuary. The average of their values $\left(Z=0.137 \mathrm{~d}^{-1}\right.$; equivalent to a $13 \%$ mortality per day) was utilized.

The weighting factor described above was multiplied by $N_{\text {sett }}$ to generate an abundance and mortalitycorrected estimate of the contribution of each fish to daily settlement. For each date, the estimated number of new settlers was summed. For comparison, estimates of daily settlement are reported with and without the mortality correction.

Comparison of the abundance of small red drum $(\leq 8 \mathrm{~mm} \mathrm{SL})$ collected on each date with the reconstructed settlement pattern indicates that the utilization of the settlement model greatly increased temporal resolution (Fig. 6). Although there was a brief period in the middle of September during which there was a distinct settlement pulse, the abundance data and estimates of daily settlement (with and without the mortality correction) suggest that the majority of the new settlers arrived in October and the first few days of November. In fact, new settlers were detected daily during October. Given the mortality rate utilized, correcting for mortality had a substantial effect on the estimates of daily settlement; in some cases the mortality-corrected number of new settlers was twice as high. 

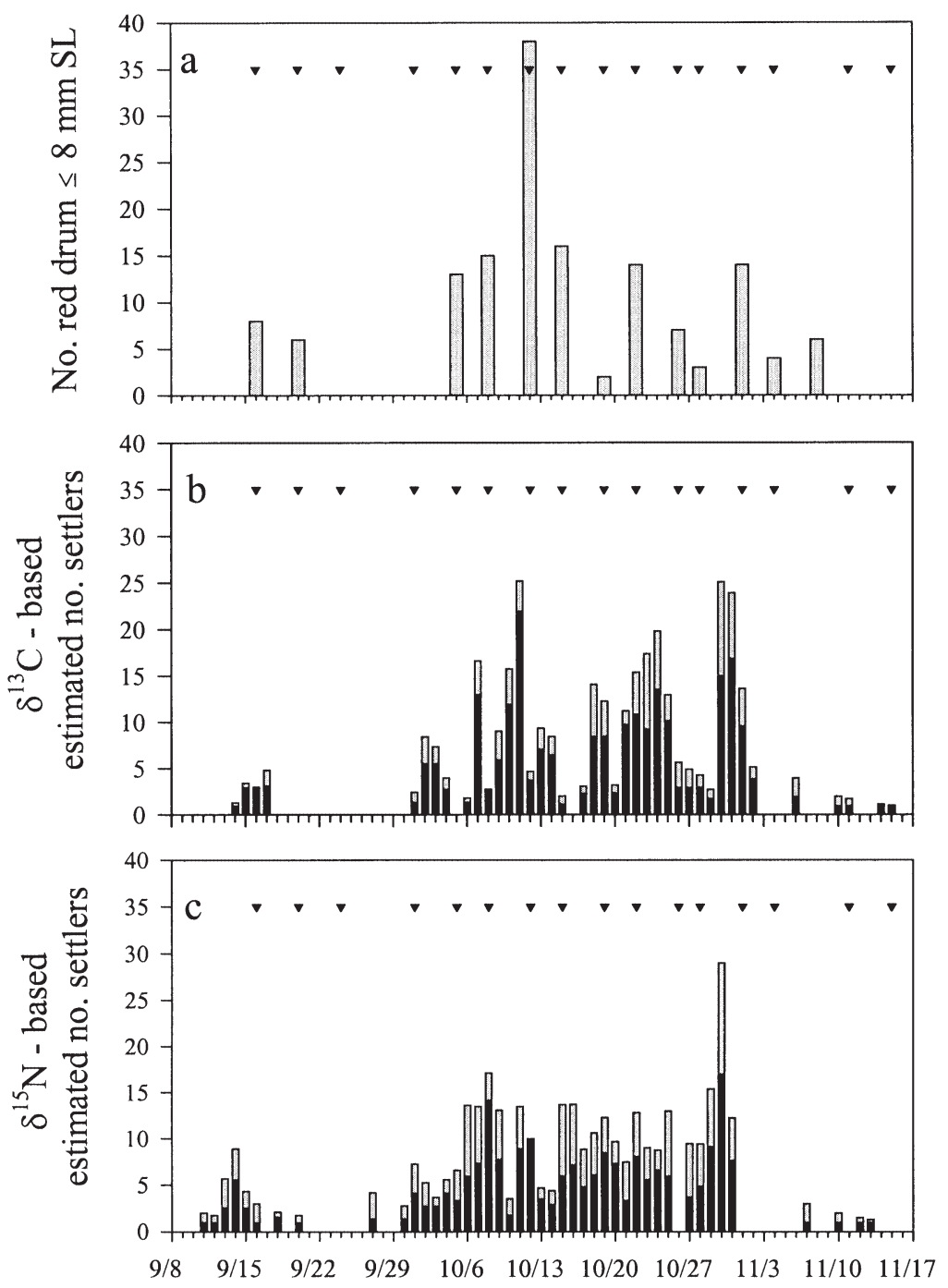

1999

Fig. 6. Sciaenops ocellatus. Number of settlement-size larvae $(\leq 8 \mathrm{~mm}$ SL) derived from analysis of length-frequency distributions of red drum collected at North Pass in 1999 (a) and number of red drum estimated to have settled on each date based on $\delta^{13} \mathrm{C}$ (b) and $\delta^{15} \mathrm{~N}$ (c) measurements and the settlement model. Black bars: abundance-corrected estimated daily settlement; graybars: abundance and mortality-corrected estimates; ( $\mathbf{v})$ : dates on which sampling was conducted $(\mathrm{mo} / \mathrm{d})$

\section{Comparison of $\delta^{13} \mathrm{C}$ and $\delta^{15} \mathrm{~N}$-based model estimates}

The carbon- and nitrogen-based data sets presented above were treated separately. Although in general the model results derived with the 2 data sets were consistent (Fig. 7), there were significant differences between the carbon and nitrogen model results for both $L_{\text {sett }}$ and $T_{\text {sett }}$ (Wilcoxon signed-ranks test; $\mathrm{p}<$ $0.001 ; \mathrm{n}=131$ ). The average deviation between the $\delta^{13} \mathrm{C}-L_{\text {sett }}$ and $\delta^{15} \mathrm{~N}-L_{\text {sett }}$ was $0.4 \mathrm{~mm} \mathrm{SL} \pm 0.5$ (mean \pm
SD); carbon- based estimates tended to yield a larger estimate of size at settlement. For $T_{\text {sett, }}$ the carbon-based estimates were $1.7 \pm 1.1 \mathrm{~d}$ earlier than those derived from nitrogen. This is consistent with the previous finding that small differences in $L_{\text {sett }}$ values lead to larger differences in the estimates of $T_{\text {sett }}$ (Herzka et al. 2001). Given the assumptions used in the model, transitional red drum can be detected up to $7 \mathrm{~d}$ (carbon) and $9 \mathrm{~d}$ (nitrogen) after settlement before they are considered equilibrated (i.e. when $\delta_{t}$ is within $2 \mathrm{SD}$ of $\left.\delta_{\text {final }}\right)$.

\section{Food web characteristics}

Since planktonic red drum have been reported to feed on particles sizes of 60 to $230 \mu \mathrm{m}$ (Lyczkowski-Shultz \& Steen 1991) and 10 to $350 \mu \mathrm{m}$ (Holt \& Holt 2000), the isotopic composition of larvae is best compared to POM $>40 \mu \mathrm{m}$. The $\delta^{13} \mathrm{C}$ and $\delta^{15} \mathrm{~N}$ of planktonic red drum was within 1 and $2 \%$, respectively, of the larger POM fractions examined (40 to $200 \mu \mathrm{m}$ and $>200$ $\mathrm{m}$ : G2 and G3 in Fig. 8). The $\delta^{13} \mathrm{C}$ of equilibrated red drum (ca-13\%) was enriched relative to marsh plants and macroalgae, similar to that of epiphytes and Spartina alterniflora and depleted relative to Halodule wrightii leaves. In addition, POM values derived from water samples collected near the study site were very depleted relative to red drum (ca-18 to $-20 \%$ ), and it is therefore unlikely that post-settlement red drum are influenced by estuarine POM. However, the presence of various carbon sources in the study area make difficult the accurate identification of specific carbon sources supporting demersal red drum. The high $\delta^{15} \mathrm{~N}$ values of planktonic and demersal red drum (13 to 15 and 8 to $9 \%$, respectively) indicate feeding at a high trophic level (Owens 1987).

\section{DISCUSSION}

This study represents a first attempt at utilizing stable isotope ratios to examine the settlement patterns of a marine fish species. Using this approach to examine the size distribution of newly settled red drum and to reconstruct daily settlement patterns provides a more 

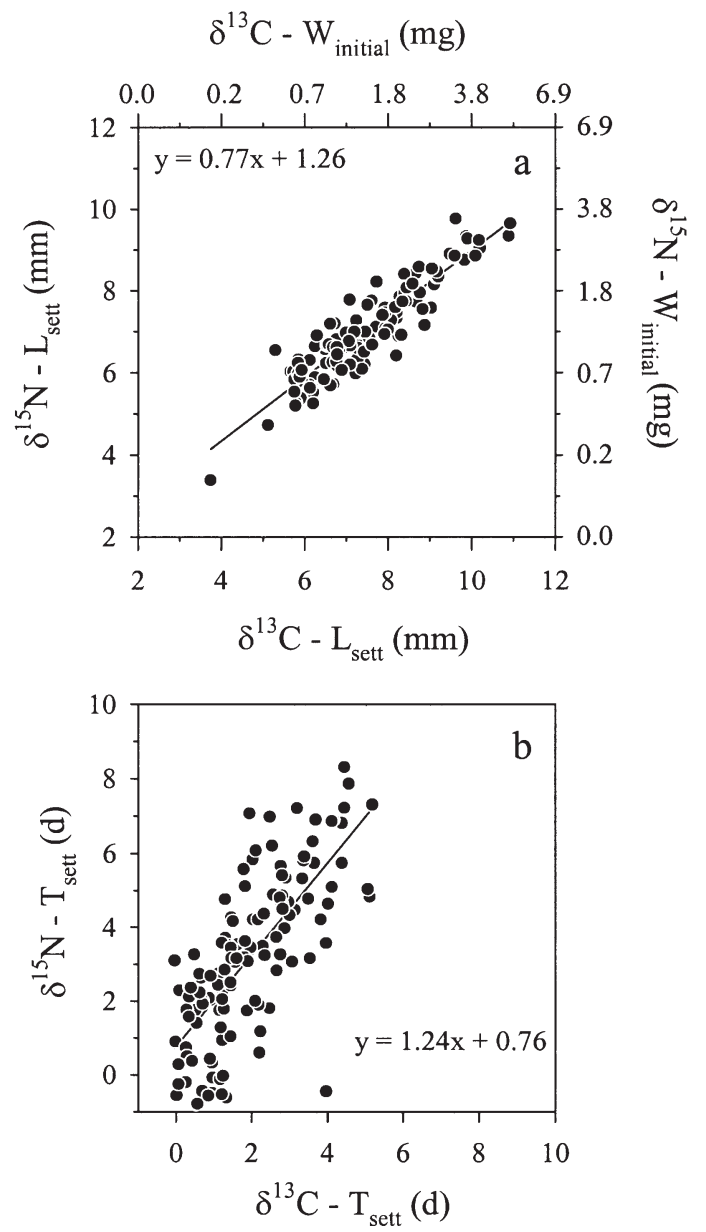

Fig. 7. Sciaenops ocellatus. Comparison of estimates of size (weight, W) at settlement $\left(L_{\text {sett }}\right)$ and time since settlement $\left(T_{\text {sett }}\right)$ derived using $\delta^{13} \mathrm{C}$ and $\delta^{15} \mathrm{~N}$ data. Data were fit with a linear model

detailed characterization of settlement than can be achieved through sampling at periodic intervals. Frequent measurement of the abundance of individuals by size class can be used to monitor settlement pulses of small fish, but cannot detect the settlement of larger individuals. The absence of morphological characters with which to identify newly settled red drum (Holt 1990), the simultaneous settlement of individuals of various sizes and the potentially confounding effect of movement within nursery habitat areas (e.g. Bell \& Westoby 1986, Jenkins \& Sutherland 1997) make it difficult to examine settlement patterns with a high temporal resolution based solely on length-frequency distributions, even when growth and mortality rates are available.

Post-settlement red drum captured during 1 collection included individuals that settled at different sizes and dates, making it practically impossible to distin-

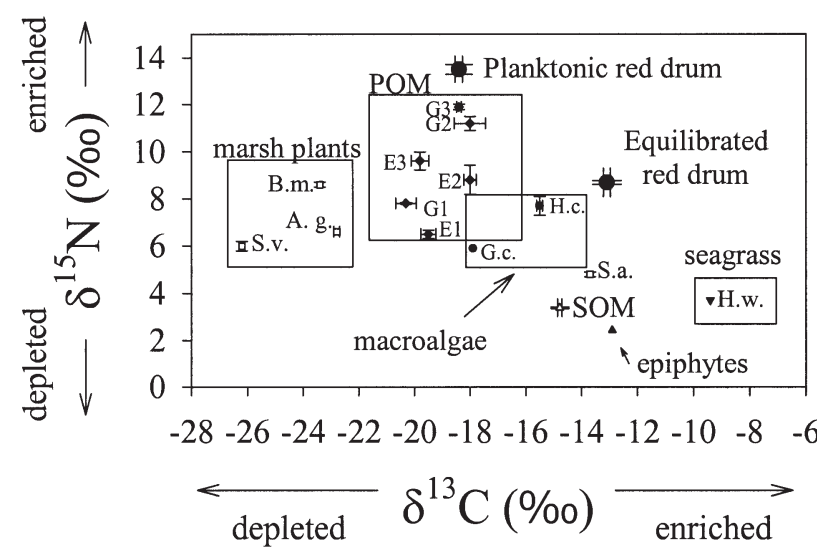

Fig. 8. $\delta^{13} \mathrm{C}$ and $\delta^{15} \mathrm{~N}$ (mean $\pm \mathrm{SE}$ ) of abundant sources of primary production, particulate organic matter (POM) and surface sediment organic matter (SOM) collected in October 1999. North Pass collections included Batis maritima (B.m.), Avicennia germinans (A.g.), Salicornia virginca (S.v.), Spartina alterniflora (S.a.), Hydropuntia cornea (H.c.), Gracilaria caudata (G.c.), Halodule wrightii (H.w.), epiphytic material on $H$. wrightii, and SOM. POM samples were collected in the estuary (E) and nearshore Gulf of Mexico (G), and were sizefractionated into 3 size ranges: 0.2 to $40 \mu \mathrm{m}(1), 40$ to $200 \mu \mathrm{m}$ (2) and $>200 \mu \mathrm{m}$ (3). Mean $\pm \mathrm{SE}$ isotopic composition of the planktonic larvae collected throughout the season and postsettlement red drum that had equilibrated on estuarine food sources is also depicted

guish between new ( 0 to $1 \mathrm{~d}$ ) and recent ( $>1 \mathrm{~d}$ ) settlers. To compare the temporal resolution of the settlement model results with that of a periodic sampling program in which the abundance of small red drum is quantified, we calculated the percent of transitional individuals $\leq 8 \mathrm{~mm}$ SL that were estimated to have settled within 0 to 1,0 to 2,0 to 3 and $\geq 4 \mathrm{~d}$ (Table 2). Based on the $\delta^{13} \mathrm{C}$ and $\delta^{15} \mathrm{~N}$ data, 69 and $37 \%$, respectively, of settlement-size individuals had settled 0 to $1 \mathrm{~d}$ prior to the date of capture. The percent of red drum that settled within 0 to $3 \mathrm{~d}$ was $95 \%$ based on $\delta^{13} \mathrm{C}$ and $75 \%$

Table 2. Sciaenops ocellatus. Number of red drum $\leq 8 \mathrm{~mm}$ standard length at the time of capture that were estimated to have settled within a specified number of days, based on isotopic measurements and the settlement model

\begin{tabular}{|lrrrr|}
\hline $\begin{array}{l}\text { Estimated } \\
\text { no. days } \\
\text { Since } \\
\text { settlement }\end{array}$ & $\begin{array}{c}\delta^{13} \mathrm{C}- \\
\text { based } \\
\text { estimate of } \\
\text { no. settlers }\end{array}$ & $\begin{array}{c}\text { Cumulative } \\
(\%)\end{array}$ & $\begin{array}{c}\delta^{15} \mathrm{~N}- \\
\text { based } \\
\text { estimate of } \\
\text { no. settlers }\end{array}$ & $\begin{array}{c}\text { Cumulative } \\
(\%)\end{array}$ \\
\hline $0-1$ & 51 & 69 & 28 & 37 \\
$0-2$ & 12 & 85 & 17 & 60 \\
$0-3$ & 7 & 95 & 11 & 75 \\
$\geq 4$ & 4 & 100 & 19 & 100 \\
$\mathbf{n}$ & $\mathbf{7 4}$ & & $\mathbf{7 5}$ & \\
\hline
\end{tabular}


based on $\delta^{15} \mathrm{~N}$ measurements. Therefore, the majority of settlement-size fish settled within 0 to $3 \mathrm{~d}$. However, this does not imply that all fish that settled within 0 to $3 \mathrm{~d}$ were $\leq 8 \mathrm{~mm} \mathrm{SL}$; only $70 \%\left(\delta^{13} \mathrm{C}\right)$ and $56 \%\left(\delta^{15} \mathrm{~N}\right)$ of settlement-size fish estimated to have settled within that time period were $\leq 8 \mathrm{~mm}$ SL (data not shown). Nevertheless, frequent measurements of the abundance of small individuals could be used to identify settlement events in studies that do not demand a high temporal resolution.

\section{Comparison of $\delta^{13} \mathrm{C}$ - and $\delta^{15} \mathrm{~N}$-based model estimates}

When applied to the carbon and nitrogen data, the settlement model should yield comparable $L_{\text {sett }}$ and $T_{\text {sett }}$ estimates for an individual. However, the settlement sizes and dates calculated using $\delta^{13} \mathrm{C}$ and $\delta^{15} \mathrm{~N}$ were not identical (Fig. 7), leading to differences in the proportion of post-settlement red drum that were estimated to have settled at various time intervals (Table 2). The differences in $L_{\text {sett }}$ (and hence $T_{\text {sett }}$ ) obtained with the carbon and nitrogen data suggest that at least one of the values used for the exponent of metabolic decay $(c=-1.4$ for carbon and $c=-1.3$ for nitrogen) may be incorrect, even though they were based on the empirical data of Herzka et al. (2001). The metabolic turnover of carbon may be overestimated (Case 1) or, alternatively, the metabolic turnover of nitrogen may be underestimated (Case 2). Applying simple dilution conditions ( $c=-1$, the theoretical limit) to the carbon data yields smaller ${ }^{13} \mathrm{C}-L_{\text {sett }}$ values and reduces the mean difference between $\delta^{13} \mathrm{C}-L_{\text {set }}$ and $\delta^{15} \mathrm{~N}-L_{\text {sett }}$ estimates to $0.15 \mathrm{~mm}$ SL (as compared to $0.44 \mathrm{~mm}$ SL: see 'Results'). On the other hand, increasing the metabolic turnover of nitrogen $(c=-2)$ results in larger $\delta^{15} \mathrm{~N}-L_{\text {sett }}$ values and a mean difference of $0.05 \mathrm{~mm}$ SL.

For metabolic turnover to be detectable based on measurements of isotopic composition, degraded products must be lost through respiratory or excretory processes. Unfortunately, the characteristics of protein degradation under varying environmental conditions has not been well established (Hawkins 1991), and little is known about the fate of degraded proteins in fish larvae (Houlihan et al. 1995). Gannes et al. (1998) suggested that the fate of carbon and nitrogen may be related to dietary protein levels and the relative utilization of lipids, carbohydrates and proteins as energy substrates. Given the complexity of the biochemical processes which underlie the breakdown and replacement of body tissues, particularly the dynamics of recycling/retention versus elimination, we cannot determine whether Case 1 or 2 (described above) is more likely to reflect the actual amount of carbon and nitrogen metabolic turnover exhibited by recently settled wild-caught red drum. The influence of environmental conditions, bioenergetic requirements and diet quality on metabolic turnover certainly warrant further research.

Nevertheless, despite the differences obtained with the carbon and nitrogen data, the length- frequency distributions generated with $\delta^{13} \mathrm{C}-L_{\text {sett }}$ and $\delta^{15} \mathrm{~N}-L_{\text {sett }}$ did not differ significantly, and most estimates of time since settlement would probably be accurate to within a 1 to $2 \mathrm{~d}$ period.

\section{Estimated size at settlement}

Based on $L_{\text {sett }}$ estimates, the smallest newly settled red drum identified in this study were 4 to $5 \mathrm{~mm}$ SL. Rooker et al. (1998a, 1999) also reported a few postsettlement red drum at this size range. However, red drum $\leq 5 \mathrm{~mm}$ SL accounted for only 2 and $4 \%\left(\delta^{13} \mathrm{C}\right.$ $L_{\text {sett }}$ and $\delta^{15} \mathrm{~N}-L_{\text {sett }}$-based values, respectively) of the total number of new settlers identified through isotopic analysis (Fig. 5e,f).

The peak settlement sizes based on $L_{\text {sett }}$ values were 6 to $8 \mathrm{~mm}$ SL $\left(72 \%\right.$ with $\delta^{13} \mathrm{C}$ - $L_{\text {sett }}$ and $84 \%$ with $\delta^{15} \mathrm{~N}$ $\left.L_{\text {sett }}\right)$. These sizes correspond well with the settlement sizes identified by Rooker et al. (1998a) based on the ascending limb of length-frequency distributions of post-settlement red drum. In addition, $25 \%\left(\delta^{13} \mathrm{C}-L_{\text {sett }}\right)$ and $12 \%\left(\delta^{15} \mathrm{~N}-L_{\text {sett }}\right)$ of transitional individuals were estimated to have settled at larger sizes. Hence, it would be difficult to identify 'large' new settlers based solely on length-frequency distributions.

An interesting aspect of the length-frequency distributions of newly settled red drum is the relatively low proportion of fishes settling at 4 to $5 \mathrm{~mm} \mathrm{SL}$. Red drum this size are abundant in collections of planktonic larvae collected in the tidal pass and Lydia Ann Channel, whereas there are fewer red drum $>6 \mathrm{~mm}$ SL (Holt et al. 1989). Likewise, other reports of the size distribution of planktonic red drum indicate that most are usually within 3 to $5 \mathrm{~mm}$ SL and that the maximum size is usually between 7 and $10 \mathrm{~mm}$ SL (Peters \& McMichael 1987, Lyczkowski-Shultz et al. 1988, Comyns et al. 1989, Lyczkowski-Shultz \& Steen 1991). The low relative abundance of large planktonic red drum (>6 mm SL) compared to the relatively large sizes of newly settled red drum collected in this study could indicate: (1) a size-dependent probability of settlement success, in which larger planktonic larvae are more likely to complete the settlement transition; and/or (2) a high and previously unaccounted-for mortality among the smallest settlers.

A size-dependent probability of settlement is likely to be particularly important for species in which the settlement transition has a substantial behavioral com- 
ponent (Boehlert \& Mundy 1988). It has been suggested that for some species of coral reef fishes, the ability to respond to the environmental cues that trigger settlement may be size-dependent (Danilowicz 1997). Higher settlement success at larger sizes could be related to a more advanced stage of development (Boehlert \& Mundy 1988). Larger and more developed individuals may also be more successful at avoiding predators (Fuiman 1994, Fuiman \& Magurran 1994).

If small settlers have high mortality, these individuals would be underepresented in length-frequency distributions. Based on the average mortality rate reported by Rooker et al. (1999), post-settlement red drum can experience a cumulative mortality of $50 \%$ over a $3 \mathrm{~d}$ period. However, these mortality estimates were derived for fish between 8 and $20 \mathrm{~mm} \mathrm{SL}$, and it is possible that smaller post-settlement red drum exhibit a substantially higher mortality. Using mesocosm experiments to evaluate the mortality of red drum late-larvae and early juveniles in habitats of varying complexity, Rooker et al. (1998b) found a significant negative relationship between mortality rates and size for 10 to $20 \mathrm{~mm}$ SL red drum. Likewise, other studies have reported size-dependent mortality in early settlers (Doherty 1982, 1983, Victor 1986).

This study was not designed to differentiate sizebased settlement success from selective mortality of small settlers. However, for the purpose of examining the temporal patterns of settlement in red drum, the effects are the same. Since small post-settlement red drum were rarely collected in this study, it is unlikely that they contributed significantly to recruitment. However, if mortality is size-dependent, then it is possible that the mortality-corrected estimates of the daily number of newly settled red drum (see following subsection) underestimated the abundance of fish settling at a smaller size.

Red drum appear to settle at a broader range of sizes than other species. The coefficient of variation (CV) for newly settled red drum was 0.18 based on $\delta^{13} \mathrm{C}-L_{\text {sett }}$ $(7.6 \pm 1.3 \mathrm{~mm} \mathrm{SL} ;$ mean $\pm \mathrm{SD})$ and 0.17 based on $\delta^{15} \mathrm{~N}$ $L_{\text {sett }}(7.1 \pm 1.2 \mathrm{~mm} \mathrm{SL})$. Victor (1991) compiled literature reports of the variation in settlement sizes exhibited by a variety of coral reef species and the estuarinedependent winter flounder Pleuronectes americanus and reported $\mathrm{CV}$ values of 0.03 to 0.08 . He suggested that the limited variability could reflect selective processes working toward an optimal size at settlement. Substantially higher variability in the size at settlement of red drum imply that this species may be less restricted in its size at settlement than those examined by Victor (1991). Hence, red drum may be competent to settle at several stages of development, although identifying the causes of the variability in settlement size of red drum was beyond the scope of this study.

\section{Temporal settlement patterns}

Most of the red drum collected in 1999 settled to the nursery habitat during October and the first few days of November, although there was a distinct and short- lived settlement event during the second half of September. Estimates of the daily number of settlers were somewhat variable, but the consistent presence of newly settled red drum during October and early November suggests a relatively continuous settlement pattern. Similarly, May \& Jenkins (1992) used otolith settlement marks and ageing techniques to examine the fine-scale temporal settlement patterns of the estuarine-dependent flounder Rhombosolea tapirina and reported a continuous settlement pattern. They suggested that their observations were attributable to either continuous spawning or to discontinuous spawning coupled with variable planktonic larval duration. Their results, and those presented in this study, differ from the settlement patterns observed for many reef species, which usually exhibit brief pulses of intense settlement followed by variable periods of negligible input (see reviews by Doherty \& Williams 1988, Doherty 1991). Such settlement patterns have been related to spawning events, physical transport processes, and variable survival during the planktonic stage. For example, Jenkins \& May (1994) identified a 10 to $14 \mathrm{~d}$ period between the settlement events of King George whiting (Sillaginoides punctata) to estuarine nursery areas in Swan Bay, Southern Australia. Based on the periodicity identified, they suggested that settlement events were driven by low-frequency oceanographic processes such as spring/neap tidal cycles, frontal systems and coastal-trapped waves.

Because of the limited scope of this study, it would be premature to draw conclusions regarding the processes underlying the observed settlement patterns. However, the continuous presence of newly settled red drum during part of the season suggests the consistent supply of potential recruits to the estuary. There is evidence to support the continuous production of offspring during the season (Wilson \& Nieland 1994), but offspring production is only 1 link in the complex chain of processes that influence the abundance of planktonic larvae and the transport of potential settlers to estuaries. Further and more detailed study of the physical and biological factors influencing the abundance and distribution of planktonic red drum is warranted.

Comparison of the estimated number of settlers derived with and without (Fig. 7) the mortality correction, underscores the importance of correcting for mortality, and of using an accurate mortality rate. Few studies have accounted for post-settlement mortality while examining the fine-scale patterns of settlement, although mortality can significantly alter apparent settlement patterns (see Jones 1991 for review). 
Table 3. Sciaenops ocellatus. Comparison of $\delta^{13} \mathrm{C}$ and $\delta^{15} \mathrm{~N}$ of pre- and post-settlement red drum larvae and early juveniles collected during 2 yr in Texas, USA

\begin{tabular}{|lccc|}
\hline & Collection date & $\begin{array}{c}\delta^{13} \mathrm{C} \\
(\%)\end{array}$ & $\begin{array}{c}\delta^{15} \mathrm{~N} \\
(\%)\end{array}$ \\
\hline Planktonic red drum & 9 Sep-9 Oct 1998 & -17.3 to -19.3 & 11.9 to 13.0 \\
& 21 Sep-26 Oct 1999 & -18.0 to -19.0 & 13.0 to 14.5 \\
Demersal red drum & 28 Sep-15 Oct 1998 & -16.5 to $-16.7^{\text {a }}$ & 11.4 to $12.9^{\mathrm{a}}$ \\
equilibrated on & 16 Sep-15 Nov 1999 & -13.1 & 8.7 \\
estuarine foods & \multicolumn{3}{l}{} \\
$\begin{array}{l}\text { aRange of } \delta^{13} \mathrm{C} \text { and } \delta^{15} \mathrm{~N} \text { of 'large' post-settlement red drum collected at 3 sites } \\
\text { in the Aransas Estuary (Herzka et al. 2001) }\end{array}$ \\
\hline
\end{tabular}

We used the average of the 2 annual instantaneous mortality rates reported for post-settlement red drum in the Aransas Estuarine system (Rooker et al. 1999). Although Rooker et al. (1999) also reported cohort-specific $Z$-values, they were temporally variable $(0.106$ to $0.265 \mathrm{~d}^{-1} ; \mathrm{n}=4$ ), and the authors were unable to identify the source of the variation in the mortality estimates. Hence, we could not incorporate this level of variability into our correction. Nevertheless, it is evident that given the importance of correcting for mortality when reconstructing settlement patterns, cohortspecific mortality rates would provide a more accurate estimate of daily settlement.

For some dates, correcting for mortality resulted in doubling the estimated number of new settlers. Based on the mortality estimate we used, the average number of newly settled red drum occurring during October was $10.2 \pm 1.4($ mean $\pm \mathrm{SE} ; \mathrm{n}=29)$ based on the $\delta^{13} \mathrm{C}$ data set, and $10.6 \pm 0.9$ based on $\delta^{15} \mathrm{~N}(\mathrm{n}=30)$. Since $75 \mathrm{~m}^{2}$ were sampled during each collection, these settlement rates are equivalent to 0.14 new settlers $\mathrm{m}^{-2} \mathrm{~d}^{-1}$.

Growth rate variations will obviously influence the estimates of $T_{\text {sett }}$. Rooker \& Holt's (1997) growth rates ranged around $\pm 20 \%$ of their mean value $\left(g=0.048 \mathrm{~d}^{-1}\right)$, which was used in this study. This amount of variation in growth rates would result in a -17 to $+26 \%$ difference in the estimate of time since settlement (Herzka et al. 2001). Although assuming constant growth rates will not severely alter the temporal settlement patterns reported in this study, the accuracy of the $T_{\text {sett }}$ estimates would increase if cohort-specific growth rates were quantified and if the recent growth histories of individuals were analyzed using otolith daily increments.

\section{Food web characteristics}

While in the planktonic and demersal habitats, red drum consume a wide array of organisms (Soto et al.
1998, Holt \& Holt 2000). The existence of differences in the isotopic signatures of planktonic red drum and equilibrated individuals collected in the nursery habitat (about $5 \%$ for $\delta^{13} \mathrm{C}$ and 4 to $5 \%$ for $\delta^{15} \mathrm{~N}$ ) indicates substantial differences in the sources of primary production and food web structure among the coastal and estuarine habitats during the fall of 1999 .

Hence, $\delta^{13} \mathrm{C}$ - and $\delta^{15} \mathrm{~N}$-based estimates were equally useful as tracers of recent settlement. However, comparison of the isotopic signatures of $\delta^{13} \mathrm{C}$ and $\delta^{15} \mathrm{~N}$ of planktonic and equilibrated red drum collected in this study with those collected during the fall of 1998 (Herzka et al. 2001) indicate substantial interannual variability in the food webs supporting the larvae in the pre- and post-settlement habitats as well (Table 3). The most striking differences were among equilibrated fish collected in the seagrass habitat in the Aransas Estuary in 1998 and 1999; there was a $~ 3.5 \%$ and a 3 to $4 \%$ difference in $\delta^{13} \mathrm{C}$ and $\delta^{15} \mathrm{~N}$ values, respectively. Although identifying the source of interannual variations in the food webs supporting red drum were beyond the scope of this study, these results indicate that using a stable isotope approach to settlement studies requires the thorough seasonal characterization of the values of $\delta_{\text {initial }}$ and $\delta_{\text {final, }}$ and that measuring both carbon and nitrogen isotope ratios is probably advisable.

During this study, the $\delta^{13} \mathrm{C}$ values of POM $>40 \mu \mathrm{m}$ ( -18 to $-19 \%$ ) collected in the coastal Gulf of Mexico were within the range expected for a phytoplanktonbased food web in subtropical waters (Fry \& Sherr 1984). Hence, planktonic red drum appear to depend on a phytoplankton-based food web. The $\delta^{13} \mathrm{C}$ of postsettlement red drum that had equilibrated on estuarine food sources $(-13.1 \%$ ) may reflect a mixture of carbon sources. In a study examining the contribution of epiphytes to the food webs in seagrass meadows of the northern Gulf of Mexico, Kitting et al. (1984) found that epiphytes $\left(\delta^{13} \mathrm{C} \approx-13 \%\right.$ ) were a significant source of carbon. While the $\delta^{13} \mathrm{C}$ of equilibrated red drum was similar to that of epiphytes, it is difficult to identify the sources of primary production using only $\delta^{13} \mathrm{C}$ data (Fry \& Sherr 1984). It is likely that the isotopic composition of red drum tissue integrates a variety of carbon sources. The high $\delta^{15} \mathrm{~N}$ values of pre- and post-settlement red drum (13 to 15 and 8 to $9 \%$, respectively) indicate that fish were feeding at a high trophic level, which is consistent with their predatory feeding habits (Soto et al. 1998, Holt \& Holt 2000). However, since the $\delta^{15} \mathrm{~N}$ of an organism can be influenced by trophic level as well as the isotopic composition of the inorganic 
nitrogen at the base of the food web (Owens 1987, Cabana \& Rasmussen 1996), it is difficult to determine whether fish in coastal areas and the estuary were feeding at different trophic levels.

\section{Conclusions}

The results presented in this study indicate that use of stable isotope ratios as natural tracers of settlement can provide insight into the fine-scale temporal settlement patterns of red drum and perhaps other marine fishes that experience an abrupt habitat and dietary shift during early life. At the population level, these results can be used to determine the timing of settlement pulses and to relate these events to physical forcing factors driving migration into estuaries, and to examine temporal coupling between the abundance of larvae in the plankton and settlement.

Acknowledgements. We are grateful to Jack D. Arnold, Scott A. Applebaum and Cameron Pratt for their extensive help during sample collection and processing. Felicia Goulet-Miler provided expert assistance during the processing of stable isotope samples. In addition, we received excellent and constructive feedback from Connie R. Arnold, Lee A. Fuiman, Ellery D. Ingall and George A. Jackson. Scott A. Applebaum, Juan Pablo Lazo and Ian McCarthy provided beneficial comments on drafts of this manuscript. We thank the 2 anonymous reviewers and Ronald T. Kneib, who provided thoughtful and interesting comments. A special thanks to Brian Fry for endorsing this project during its initial stages. This work was supported by a grant from NOAA Office of Sea Grant, Department of Commerce, under Grant NA86RG0058 to the Texas Sea Grant College Program. This is Contribution 1180 of the University of Texas at Austin Marine Science Institute.

\section{LITERATURE CITED}

Bass RJ, Avault JWJ (1975) Food habits, length-weight relationship, condition factor, and growth of juvenile red drum, Sciaenops ocellata, in Louisiana. Trans Am Fish Soc 1:35-45

Bell JD, Westoby M (1986) Variation in seagrass height and density over a wide spatial scale: effects on common fish and decapods. J Exp Mar Biol Ecol 104:275-295

Bell JD, Steffe AS, Westoby M (1988) Location of seagrass beds in estuaries: effects on associated fish and decapods. J Exp Mar Biol Ecol 122:127-146

Boehlert GW, Mundy BC (1988) Roles of behavior and physical factors in larval and juvenile fish recruitment to estuarine nursery areas. Am Fish Soc Symp 3:51-67

Brown AL, Bailey KM (1992) Otolith analysis of juvenile wallaye pollock Theragra chalcogramma from the western Gulf of Alaska. Mar Biol 112:23-30

Brown, CA, Jackson GA, Brooks, DA (2000) Particle transport through a narrow inlet due to tidal forcing and implications for larval transport. J Geophys Res 105:24141-24156

Cabana G, Rasmussen JB (1996) Comparison of aquatic food chains using nitrogen isotopes. Proc Natl Acad Sci USA 93:10844-10847

Comyns BH, Lyczkowski-Shultz J, Rakocinski CF, Steen JPJ
(1989) Age and growth of red drum larvae in the NorthCentral Gulf of Mexico. Trans Am Fish Soc 118:159-167

Danilowicz BS (1997) The effects of age and size on habitat selection during settlement of a damselfish. Environ Biol Fish 50:257-265

Deegan LA, Garritt RH (1997) Evidence for spatial variability in estuarine food webs. Mar Ecol Prog Ser 147:31-47

DeNiro MJ, Epstein S (1978) Influence of diet on the distribution of carbon isotopes in animals. Geochim Cosmochim Acta 42:495-506

DeNiro MJ, Epstein S (1981) Influence of diet on the distribution of nitrogen isotopes in animals. Geochim Cosmochim Acta 45:341-351

Doherty PJ (1982) Some effects of density on the juveniles of two species of tropical, territorial damselfishes. J Exp Mar Biol Ecol 65:249-261

Doherty PJ (1983) Tropical damselfishes: is density limited by agression or recruitment? Ecology 64:176-190

Doherty PJ (1991) Spatial and temporal patterns in recruitment. In: Sale PF (ed) The ecology of fishes on coral reefs. Academic Press, San Diego, p 261-293

Doherty PJ, Williams DMcB (1988) The replenishment of marine fish populations. Oceanogr Mar Biol Annu Rev 26: 487-551

Fortier L, Leggett WC (1983) Vertical migration and transport of larval fish in a partially mixed estuary. Can J Fish Aquat Sci 40:1543-1555

France RL (1995) Carbon-13 enrichment in benthic compared to planktonic algae: foodweb implications. Mar Ecol Prog Ser 124:307-312

Fry B (1983) Fish and shrimp migrations in the northern Gulf of Mexico analyzed using stable $\mathrm{C}, \mathrm{N}$, and $\mathrm{S}$ isotope ratios. Fish Bull 81:789-801

Fry B, Arnold CR (1982) Rapid $\delta^{13} \mathrm{C} / \delta^{12} \mathrm{C}$ turnover during growth of brown shrimp (Panaeus aztecus). Oecologia 54: 200-204

Fry B, Sherr EB (1984) $\delta^{13} \mathrm{C}$ measurements as indicators of carbon flow on marine and freshwater ecosystems. Contrib Mar Sci 27:13-47

Fuiman LA (1994) The interplay of ontongeny and scaling in the interactions of fish larvae and their predators. J Fish Biol 45(Suppl A):55-79

Fuiman LA, Magurran AE (1994) Development of predator defenses in fishes. Rev Fish Biol Fish 4:145-183

Gannes LZ, Martinez del Rio C, Koch P (1998) Natural abundance variations in stable isotopes and their potential uses in animal physiological ecology. Comp Biochem Physiol 119:725-737

Hawkins AJS (1991) Protein turnover: a functional appraisal. Funct Ecol 5.222-233

Herzka SZ (2000) Characterization of the recruitment patterns of red drum (Sciaenops ocellatus) larvae to estuarine nursery habitat using stable isotopes as natural tracers of settlement. PhD thesis, University of Texas at Austin

Herzka SZ, Holt GJ (2000) Changes in isotopic composition of red drum (Sciaenops ocellatus) larvae in response to dietary shifts: potential applications to settlement studies. Can J Fish Aquat Sci 57:137-147

Herzka SZ, Holt SA, Holt GJ (2001) Documenting the settlement history of individual fish larvae using stable isotope ratios: model development and validation. J Exp Mar Biol Ecol 265:49-74

Holt GJ (1990) Growth and development of red drum eggs and larvae. In: Chamberlain GW, Miget RJ, Haby MG (eds) Red drum aquaculture. Texas A\&M University Sea Grant College Program, Galveston, Texas, No. TAMU- SG90-603, p 46-50 
Holt GJ, Holt SA (2000) Vertical distribution and the role of physical processes in the feeding dynamics of two larval sciaenids Sciaenops ocellatus and Cynoscion nebulosus. Mar Ecol Prog Ser 193:181-190

Holt SA, Holt GJ, Arnold CR (1989) Tidal stream transport of larval fishes into non-stratified estuaries. Rapp P-V Réun Int Explor Mer 191:100-104

Houlihan DF, Pedersen BH, Steffensen JF, Brechin J (1995) Protein synthesis, growth and energetics of larval herring (Clupea harengus) at different feeding regimes. Fish Physiol Biochem 14:195-208

Jenkins GP, May HMA (1994) Variation in settlement and larval duration in King George whiting, Sillaginoides punctata (Sillaginidae), in Swan Bay, Victoria, Australia. Bull Mar Sci 54:281-296

Jenkins GP, Sutherland CR (1997) The influence of habitat structure on nearshore fish assemblages in a southern Australian embayment: colonisation and turnover rate of fishes associated with artificial macrophyte beds of varying physical structure. J Exp Mar Biol Ecol 218:103-125

Jones GP (1991) Postrecruitment processes in the ecology of coral reef fish populations: a multifactorial perspective. In: Sale PF (ed) The ecology of fishes on coral reefs. Academic Press, San Diego, p 294-328

Kitting CL, Fry B, Morgan MD (1984) Detection of inconspicuous epiphytic algae supporting food webs in seagrass meadows. Oecologia 62:145-149

Levin P, Petrick R, Malone J (1997) Interactive effects of habitat selection, food supply and predation on recruitment of an estuarine fish. Oecologia 112:55-63

Lyczkowski-Shultz J, Steen JPJ (1991) Diel vertical distribution of red drum Sciaenops ocellatus larvae in the northcentral Gulf of Mexico. Fish Bull 89:631-641

Lyczkowski-Shultz J, Steen JP, Comyns BH (1988) Early life history of red drum (Sciaenops ocellatus) in the Northcentral Gulf of Mexico. Final Report, Mississippi-Alabama Sea Grant Consortium, Ocean Springs, Mississippi

May HMA, Jenkins GP (1992) Patterns of settlement and growth of juvenile flounder Rhombosolea taparina determined from otolith microstructure. Mar Ecol Prog Ser 79: 203-214

McCormick MI (1994) Variability in age and size at settlement of the tropical goatfish Upeneus tragula (Mullidae) in the northern Great Barrier Reef lagoon. Mar Ecol Prog Ser 103:1-15

Milicich MJ, Meekan MG, Doherty PJ (1992) Larval supply: a good predictor of recruitment of three species of reef fishes (Pomacentridae). Mar Ecol Prog Ser 86:153-166

Miller JM (1988) Physical processes and the mechanisms of

Editorial responsibility: Ronald Kneib (Contributing Editor), Sapelo Island, Georgia, USA coastal migration of immature marine fishes. Am Fish Soc Symp 3:68-76

Norcross BL, Shaw RF (1984) Oceanic and estuarine transport of fish eggs and larvae: a review. Trans Am Fish Soc 113: 153-165

Owens NJP (1987) Natural variations in ${ }^{15} \mathrm{~N}$ in the marine environment. Adv Mar Biol 24:389-451

Peters KM, McMichael RHJ (1987) Early life history of the red drum, Sciaenops ocellatus (Pisces: Sciaenidae) in Tampa Bay, Florida. Estuaries 10:92-107

Rooker JR, Holt SA (1997) Utilization of subtropical seagrass meadows by newly settled red drum Sciaenops ocellatus: patterns of distribution and growth. Mar Ecol Prog Ser 158:139-149

Rooker JR, Holt SA, Soto MA, Holt GJ (1998a) Postsettlement patterns of habitat use by sciaenid fishes in subtropical seagrass meadows. Estuaries 21:318-327

Rooker JR, Holt GJ, Holt SA (1998b) Vulnerability of newly settled red drum (Sciaenops ocellatus) to predatory fish: is early-life survival enhanced by seagrass meadows? Mar Biol 131:145-151

Rooker JR, Holt SA, Holt GJ, Fuiman LA (1999) Spatial and temporal variability in growth, mortality, and recruitment potential of postsettlement red drum, Sciaenops ocellatus, in a subtropical estuary. Fish Bull 97:581-590

Shenker JM, Maddox ED, Wishinski E, Pearl A, Thorrold SR, Smith N (1993) Onshore transport of settlement-stage Nassau grouper Epinephelus striatus and other fishes in Exuma Sound, Bahamas. Mar Ecol Prog Ser 98:31-43

Sogard SM, Able HW (1994) Diel variation in immigration of fishes and decapod crustaceans to artificial seagrass habitat. Estuaries 17:622-630

Soto MA, Holt GJ, Holt SA, Rooker J (1998) Food habits and dietary overlap of newly settled red drum (Sciaenops ocellatus) and Atlantic croaker (Micropogonias undulatus) from Texas seagrass meadows. Gulf Res Rep 10:41-55

Victor BC (1986) Larval settlement and juvenile mortality in a recruitment-limited coral reef fish population. Ecol Monogr 56:145-160

Victor BC (1991) Settlement strategies and biogeography of reef fishes. In: Sale PF (ed) The ecology of fishes on coral reefs. Academic Press, San Diego, p 231-260

Weinstein MP, Weiss SL, Hodson RG, Gerry LR (1980) Retention of three taxa of postlarval fishes in an intensively flushed tidal estuary, Cape Fear River, North Carolina. Fish Bull 78:419-435

Wilson CA, Nieland DL (1994) Reproductive biology of red drum, Sciaenops ocellatus, from the neritic waters of the northern Gulf of Mexico. Fish Bull 92:841-850

Submitted: November 12, 2000; Accepted: May 27, 2001

Proofs received from author(s): January 22, 2002 